\title{
Anaerobic codigestion of biowastes generated in Castilla-La Mancha (Spain): batch studies
}

\author{
L. Rodríguez, J. Villaseñor, V. Sánchez, F. J. Fernández \\ \& I. M. Buendía \\ Department of Chemical Engineering. ITQUIMA, \\ University of Castilla-La Mancha, Spain
}

\begin{abstract}
The combined anaerobic treatment of waste activated sludge (WAS) with olive oil mill wastes (OMW) and waste activated sludge with wine vinasses (VN), was investigated in batch reactors. The codigestion was studied by mixing the WAS with different ratios of OMW or VN. The criteria used for judging the success of the codigestion was the COD reduction, total methane production and methane yield. The results indicate that COD removal is better when biowastes are mixed. Total methane production in codigestion was higher than that from anaerobic digestion of raw wastes. A maximum was reached when WAS:OMW and WAS:VN were mixed in ratios of 6:94 and 25:75, respectively. When the ratio of OMW was increased in the mixture, the total methane production decreased. This effect could be explained because of the inhibition caused by the polyphenol contained in this waste.

Keywords: anaerobic digestion, codigestion, olive oil mill waste, wine vinasses waste activated sludge.
\end{abstract}

\section{Introduction}

Agro-industries play a significant role in and represent a considerable share of the Spanish economy, mainly in central Spain in regions such as Castilla-La Mancha. Every year 1.4-1.8 million tons of olive oil are produced in Mediterranean countries, resulting in 30 million $\mathrm{m}^{3}$ waste [1]. Amongst other wastes, the main agro-industrial wastes generated in Castilla-La Mancha are olive oil mill wastes and wine vinasses. The food and drink industry of CastillaLa Mancha represents the $28.25 \%$ of the regional industry. These industries 
produce a high volume of wastes. In 2003, for instance, 5 million tons of wastes were generated by this kind of industries in Spain [2]. Nevertheless, a fraction of these agro-wastes can be considered a by-product and can be useful to other industries. This has many environmental and economic advantages and allows the natural resources contained in the waste to be recovered.

The biowaste mentioned above present certain problems, such as a high COD content, disproportionate $\mathrm{C} / \mathrm{N} / \mathrm{P}$ ratio, high generation rate, seasonal production and expensive management and storage. In view of these problems, anaerobic digestion seems to be a reasonable solution whose performance could be increased by mixing different biowastes (anaerobic codigestion), which leads to better conditions for the growth of microorganisms.

The co-digestion is expected to be cheaper than the treatment of individual waste, mainly due to the lower cost per volume treated, and because the moisture and rheological conditions can be adjusted. In addition, by mixing the wastes, the inhibitory and toxic effects of certain compounds can be minimised. Furthermore, global methane production can be higher than the amount generated by the addition of the methane generated by the digestion of the individual wastes [3-5].

In this context, the aim of this work was to study the feasibility of anaerobic codigestion of WAS, OMW, VN from Castilla-La Mancha (Spain) in batch reactors.

\section{Materials and methods}

\subsection{Substrates and inoculum}

Activated waste sludge was picked up from the wastewater treatment plant situated in Ciudad Real (Spain).

Olive oil mill waste came from Aceites Pina located in Villarta de San Juan (Ciudad Real, Spain).

Wine vinasses came from Bodegas Cruz-Vega, in Madridejos (Toledo, Spain).

The inoculum used in the batch experiments was taken from the anaerobic digester of the Ciudad Real wastewater treatment plant.

\subsection{Batch experiments}

The co-digestion was studied in $1 l$ batch digesters with a working volume of $250 \mathrm{~mL}$ and a temperature of $35^{\circ} \mathrm{C}$. The inoculum was concentrated until it reached a volatile suspended solid content of $10000 \mathrm{mg} / \mathrm{L}$. The experiments were duplicated and the results were evaluated by comparing the rate of methane production in the headspace of the reactors $(750 \mathrm{~mL})$. During the experiments, the pressure in the gas phase was measured with barometric sensors incorporated at the top of the reactors. In addition, control experiments were carried out to determine the endogenous biogas production.

Mixtures of WAS, OMW and ultra pure water, like mixtures of WAS, VN and ultra pure water, at different mixed ratios from 0 to $100 \%$, were performed to 
evaluate the potential degradation efficiency and inhibition. The length of each experiment was about 1 month.

\subsection{Analytical methods}

Using the methods described previously in literature, the methane and carbon dioxide contents of biogas and VFA in the bulk liquid were measured by GC [6]. Volatile solids (VS), total solids (TS), COD and $\mathrm{pH}$ were determined using Standard Methods [7]. Total nitrogen, total phosphorus and dissolved nitrogen were also determined using Standard Methods [7].

\section{Results and discussion}

\subsection{Waste characterisation}

The characterisation of the waste used in the experiments was carried out following a standard procedure [8]. The results of the characterisation are presented in Table 1. The results indicate that the codigestion of the wastes is feasible and could be the best option for degrading these wastes.

For example, the $\mathrm{pH}$ of WAS was higher than that of OMW, and WAS would compensate the OMW pH deficiency, allowing the growth of the methanogenic bacteria. The $\mathrm{C} / \mathrm{N} / \mathrm{P}$ ratio in the mixtures was more suitable for anaerobic treatment than the individual $\mathrm{C} / \mathrm{N} / \mathrm{P}$ ratio.

Table 1: Characterisation of the wastes.

\begin{tabular}{|l|c|c|l|c|}
\hline & WAS & VN & & OMW \\
\hline TS (g/L) & 21 & 20 & TS $(\%)$ & 46.42 \\
\hline VS (g/L) & 18 & 14 & VS $(\%)$ & 44.28 \\
\hline COD (g/L) & 32 & 22 & COD $(\mathrm{g} / \mathrm{L})$ & 685 \\
\hline $\mathrm{pH}$ & 6.89 & 6.86 & $\mathrm{pH}$ & 5.62 \\
\hline Total N (mg-N/L) & 80 & 9.7 & Total N (mg-N/g)* & 0.35 \\
\hline Total P (mg-P/L) & 3.6 & 1.2 & Total P (mg-P/g)* & 0.003 \\
\hline Ammonia (mg-N/L) & 16.3 & 1.2 & Ammonia (mg-N/g)* & 0.22 \\
\hline
\end{tabular}

*gram of wet waste.

\subsection{Batch experiments}

Several batch experiments were carried out to study the anaerobic treatment of the biowaste mentioned above and to evaluate the influence of the mixture ratios.

Figures 1 and 2 show the cumulative biogas production of each feedstock separately WAS, OMW and VN and three mixtures vs. reaction time in the batch reactors.

Regarding both Figures 1 and 2, cumulative biogas production was higher when WAS was mixed with OMW and with VN. These results indicated that codigestion increased the anaerobic biodegradability. 
As a summary of the results, the COD reduction (\%) and cumulative biogas production expressed as total methane production $\left(\mathrm{mg} \mathrm{COD}_{\text {methane }} / \mathrm{L}\right)$ are showed in Table 2.

These results indicate that COD removal was also better when biowastes were mixed.

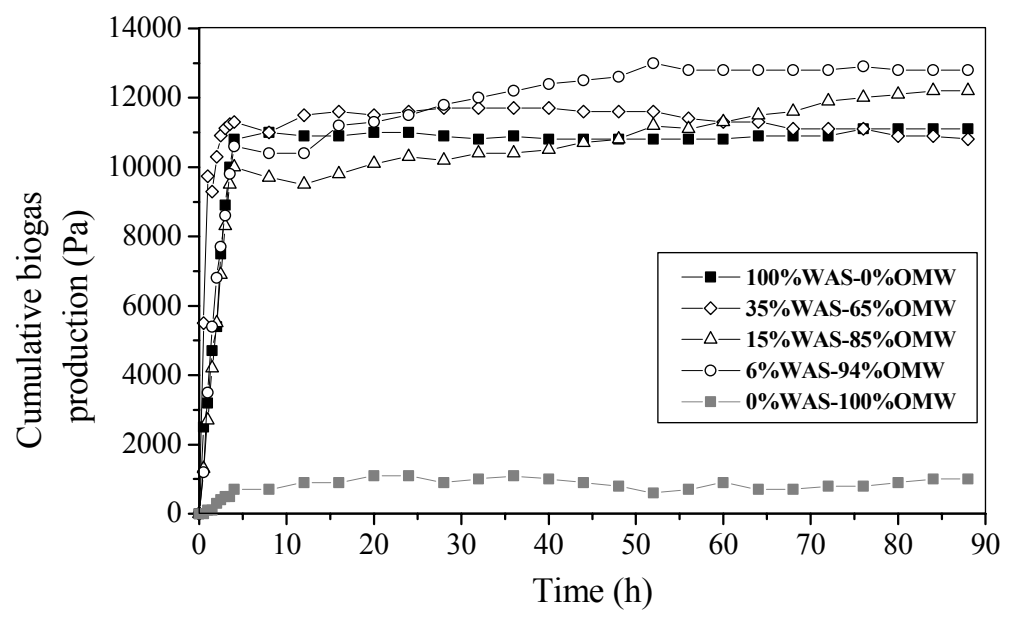

Figure 1: Codigestion of WAS and OMW. Cumulative Biogas Production.

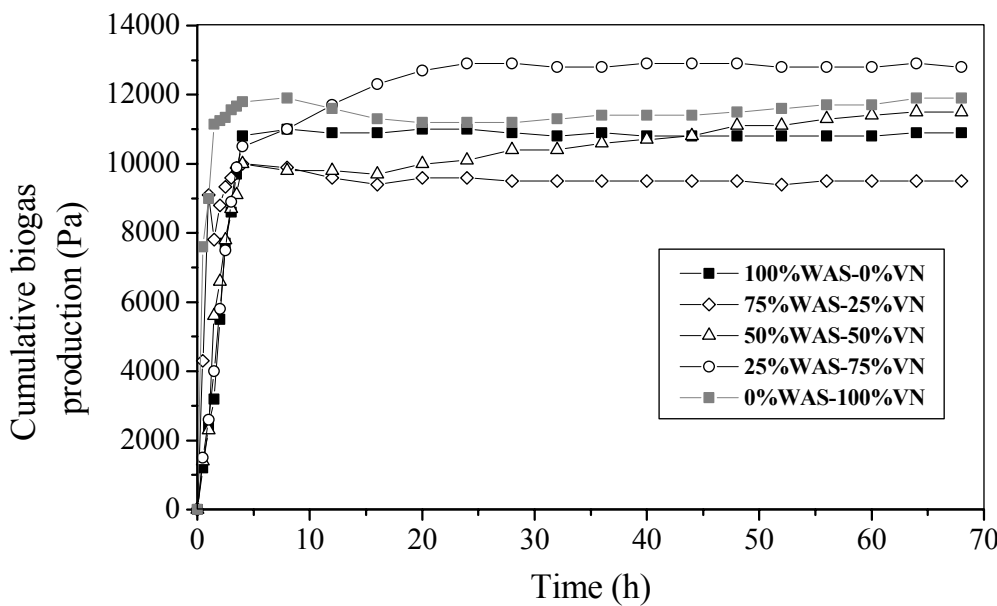

Figure 2: Codigestion of WAS and VN. Cumulative Biogas Production. 
Table 2: COD reduction $(\%)$ and Total methane production (mg COD methane $/ \mathrm{L})$.

\begin{tabular}{|c|c|c|c|c|c|}
\hline WAS:OMW & $\begin{array}{c}\text { COD } \\
\text { reduction }\end{array}$ & $\begin{array}{c}\text { Methane } \\
\text { production }\end{array}$ & WAS:VN & $\begin{array}{c}\text { COD } \\
\text { reduction }\end{array}$ & $\begin{array}{c}\text { Methane } \\
\text { production }\end{array}$ \\
\hline $100: 0$ & 58.25 & 947.20 & $100: 0$ & 58.25 & 947.20 \\
\hline $35: 65$ & 56.08 & 998.40 & $75: 25$ & 46.88 & 870.40 \\
\hline $15: 85$ & 57.06 & 1126.40 & $50: 50$ & 56.61 & 1100.80 \\
\hline $6: 94$ & 78.53 & 1152.00 & $25: 75$ & 59.83 & 1152.00 \\
\hline $0: 100$ & 66.56 & 102.40 & $0: 100$ & 53.91 & 1100.80 \\
\hline
\end{tabular}

\subsubsection{WAS:OMW codigestion}

Regarding Table 2, the most suitable mixture to be anaerobically codigested, in terms of COD reduction, is 6:94 (WAS:OMW). This value is not in accordance with the theoretical mass balance, which indicated that mixtures with higher amounts of WAS were more efficient than OMW. This can be explained, as not all fractions of $\mathrm{C} / \mathrm{N} / \mathrm{P}$ were available to the methanogenic bacteria. In the case of the OMW, some of the nutrients contained are in the olive stone and this cannot be digested by anaerobic biomass within such a short time. When the amount of OMW is increased, total methane production decreased due to inhibitory effects of polyphenols on methanogenic bacteria [9].

\subsubsection{WAS: VN codigestion}

The methane production obtained at the end of the experiment for the WAS and $\mathrm{VN}$ were 947.20 and $1100.80 \mathrm{mg} \mathrm{COD}_{\text {methene }} / \mathrm{L}$, respectively, indicating that these wastes were of a similar biodegradability. When WAS and VN were codigested in a ratio of 25:75, a maximum in the COD reduction and methane production was reached. However, the values of these parameters were very similar when single wastes were digested.

\section{Conclusions}

The results and evaluations of this study may be summarised as follows:

- In the batch reactors, it was found that both COD removal and total methane production increased when biowastes were mixed.

- A maximum was reached when WAS:OMW and WAS:VN were mixed in ratios of 6:94 and 25:75, respectively.

- It was observed that by increasing the amount of OMW, the total methane production decreased due to inhibitory effects of polyphenols.

\section{References}

[1] Angelidaki, I., Ahring, B.K., Deng, H. \& Schmidt, J.E., Anaerobic digestion of olive oil mill effluents together with swine manure in UASB reactors. Water Science and Technology, 45 (10), pp. 213-218, 2002. 
[2] National Institute of Statistics, Encuesta industrial de empresa, Spain, 2003.

[3] Angelidaki, I. \& Ahring, B.K., Codigestion of olive mill wastewaters with manure, household waste or sewage sludge. Biodegradation, 8 (4), pp.221-226, 1997.

[4] Marques, I., Anaerobic digestion treatment of olive mill wastewaters for effluent re-use in irrigation. Desalination, 137, pp. 233-239, 2000.

[5] Monnet, F., An introduction to anaerobic digestion of organic wastes. Remade Scotland, pp. 1-48, 2003.

[6] Angelidaki, I., Petersen, S.P. \& Anhring, B.K., Effects of lipids on thermophilic anaerobic digestion and reduction of lipid inhibition upon addition of bentonite. Applied Microbiology Technology, 33, pp. 469-472, 1990.

[7] APHA-AWWA-WPCF, Standard Methods for the Examination of Waste and Wastewater, American Public Health Association, Washington, DC, 1998.

[8] Federal Compost Quality Assurance Organization (FCQAO), Methods book for the analysis of Compost, Bundesgütegemeinschaft Kompost e.V., Germany, 1994.

[9] Fountoulskid, M.S., Dokianakis, S.N., Kornaros, M.E., Aggelis, G.G., Lyberatos, G., Removal of phenolic in olive mill wastewaters using the white-rot fungus Pleurotus ostreatus. Water Research, 36 (19), pp. 4735 4744, 2002. 